LAV because the virus has not been transmitted to a permanently growing cell line for true isolation...".

Popovic, who in 1983 and 1984 was the first anywhere to get an AIDS virus to grow in sufficient quantity to develop a test to detect the virus in the blood supply, had actually transmitted LAV to a cell line, although it did not grow well or for long and the Gallo group did not attempt to characterize it. Gallo says the sentence is intended to refer only to the fact that the French had not grown LAV in a permanent cell line (which they had not). The May NIH/OSI report decided that the reference was ambiguous but found no evidence to refute Gallo's explanation.

But ORI concluded instead that "Gallo falsely reported the status of LAV research" in the paper and is therefore guilty of scientific misconduct. In an odd twist, the ORI report simultaneously concurs with the NIH/ OSI finding that Popovic is guilty while also coming very close to saying it does not matter. "The confirmed scientific misconduct on the part of Dr Popovic is relatively minor", it states, "does not invalidate the findings of his breakthrough research and should not preclude his employment as a scientist." (Popovic has been out of work for nearly two years.)

Gallo, who says that he will appeal, calls ORI's interpretation of the controversial sentence "utterly unwarranted" and the investigators "incompetent". Popovic is also expected to appeal. "There is no evidentiary basis for any finding of scientific misconduct", says his attorney, Barbara F. Mishkin.

And so the case goes on, with energy on both sides of the Atlantic being diverted from the fight against AIDS.

Barbara J. Culliton

\section{EC increases Framework budget}

London. Research ministers from the 12 member states of the European Communities (EC), under pressure to reach a decision by the end of the year, agreed two days before Christmas to spend more on the final two years of the Third Framework Programme, through which the EC Commission supports its joint research projects.

The ministers agreed to provide an extra ECU900 million (US\$1.2 billion), spread over 1993 and 1994. The new money will mean an increase of 13.3 per cent for most of the 15 programmes under the Framework umbrella. However, fusion energy (which is on a different budget cycle) will receive an additional 24 per cent and non-nuclear energies will get 38 per cent more.

The final figure is a compromise between an increase of ECU750 million that the British government wanted and as much as ECU1.5 billion sought by the European Commission.

David Dickson

Forecast 1993

Nature takes a look into its crystal ball at prospects over the next 12 months in several important areas relating to research and the scientific community.

\section{Eastern Europe}

Three years after the fall of the German Democratic Republic triggered a domino collapse of communist states in Central and Eastern Europe, celebrations of the new year have lost their sparkle. The arrival of

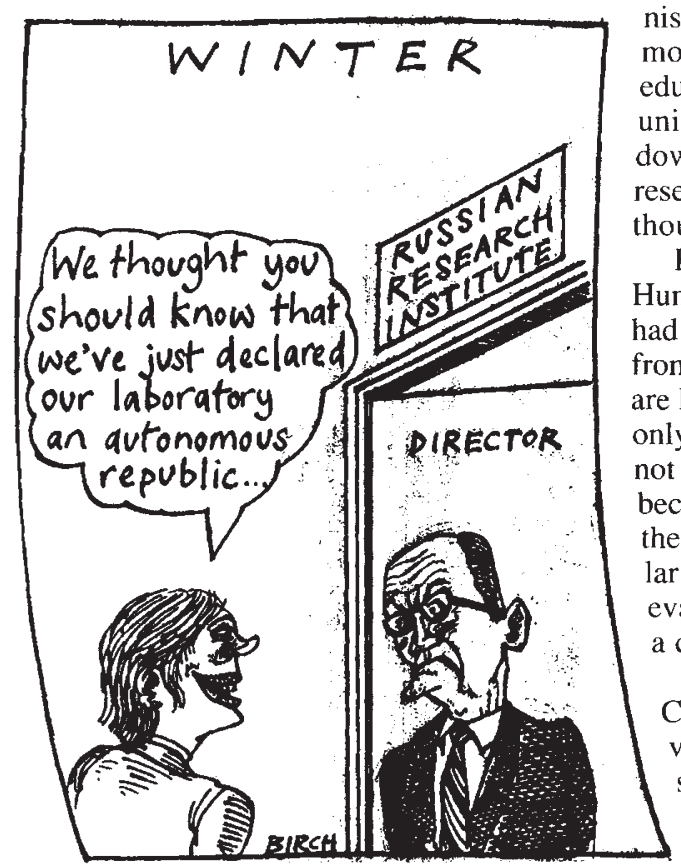

1990 was greeted with unsurpassed optimism; by contrast, the mood in 1993 could hardly be more different.

Holding up the best is the former East Germany itself. Universities and research centres, restructured along Western lines with formidable speed and determination, were relaunched on 1 January this year on the same legal basis as those in western Germany. In the past three years, the German Academy of Sciences and its institutes have been dismantled, but two new national research centres and two Max Planck Institutes (plus eight departments) have been founded. Nineteen applied research Fraunhofer Institutes set up in 1991 must meet their goals by the end of this year or face closing.

Although the stage is now set for a bright long-term future, it has not been an easy three years. Academic pay is still only 80 per cent of that in the west, and no-one knows the fate of the tens of thousands of scientists dismissed from overstaffed institutes during the ruthlessly enforced renewal process.

Although the methods have caused pain and resentment, the worst is now over. More intractable problems face other countries struggling to establish a science base in their new democracies.

Money is in short supply everywhere, but science reform and restructuring (usually a euphemism for redundancies) have proceeded very gradually because of social resistance. Most Central and Eastern European countries had followed the communist model, itself based on the French model, of separating research from higher education. Reestablishing links between universities and research and breaking down the political powers in scientific research has been more difficult than first thought.

Furthest along the track are Poland and Hungary, where universities and academies had managed to maintain their distance from the communist party. Furthest behind are Romania and Bulgaria. Romania is the only former communist country that has not tried to evaluate its research activities because of the extensive damage done by the Ceaucescu regime. Bulgaria, in a similar but less severe situation, planned an evaluation last October but failed to reach a consensus on how to proceed.

Between the extremes lies the former Czechoslovakia, whose decision to divide delayed the reform process on both sides. Czech research is relatively strong but academic restructuring has hardly begun. By contrast, Slovak research is weaker but its academic system has always been more liberal. The Czech Republic starts the new year with a new, government-directed research plan; Slovakia hopes to institute a science policy by April.

Science in the former Soviet Union probably faces a prolonged economic crisis. Many fear the disintegration of an infrastructure that once provided pockets of world-class research.

Central and Eastern European countries continue to call for foreign aid as short-term measures to help stem the flow of scientists to the West. The European Commission has recently allocated ECU55 million to fund cooperative projects during 1993. Individual institutes - and some individuals - in the East have offered help of various sorts, and the solidarity within certain close-knit international communities, such as astrophysics, has also meant practical support for some projects.

But these initiatives are dwarfed by an economic depression on a scale not seen for decades in Western Europe. In such circumstances, science and research will remain low on any government's list of priorities in 1993.

Alison Abbott 